\title{
PENGARUH KONFLIK PERAN GANDA DAN PSYCHOLOGICAL WELL- BEING TERHADAP KINERJA (Studi Pada Perawat Wanita RSUD S.K.Lerik Kota Kupang)
}

\author{
Ummi Rosdiayanti Jalil1 ${ }^{1}$, Rolland Epafras Fanggidae ${ }^{2}$, Apriana H.J. Fanggidae ${ }^{3}$ \\ ${ }^{1,2,3}$ Universitas Nusa Cendana, rolland_fanggidae@ @staf.undana.ac.id
}

\begin{abstract}
ABSTRAK
Tujuan dari penelitian ini adalah untuk menggambarkan pengaruh konflik peran ganda dan kesejahteraan psikologis terhadap kinerja perawat wanita di Rumah Sakit Umum S.K.Lerik Kota Kupang. Metodologi penelitian: Penelitian dilakukan dengan pendekatan kualitatif. Pengumpulan data dilakukan dengan mengisi kuesioner oleh 38 perawat wanita yang dijadikan sampel. Pemrosesan data dilakukan dengan analisis regresi linier berganda. Hasil: Hasil penelitian ini menunjukkan pengaruh variabel konflik peran ganda dan kesejahteraan psikologis terhadap kinerja perawat wanita di RSUD S.K.Lerik Kota Kupang baik secara parsial maupun simultan. Keterbatasan: Penelitian ini hanya membahas pengaruh variabel konflik peran ganda dan kesejahteraan psikologis terhadap kinerja perawat wanita di Rumah Sakit Regional S.K.Lerik di Kupang. Kontribusi: Penelitian ini dapat digunakan sebagai informasi ilmiah di bidang manajemen sumber daya manusia .
\end{abstract}

Kata Kunci : Konflik Peran Ganda, Kesejahteraan Psikologis, Kinerja

\begin{abstract}
The purpose of this study is to describe the effect of double role conflict and psychological wellbeing on the performance of female nurses in S.K.Lerik Public Hospitals Kupang City. Research methodology: The study was conducted with a qualitative approach. Data collection was carried out by filling out the questionnaire by 38 female nurses who were sampled. Data processing is performed by multiple linear regression analysis. Results: The results of this study indicate the influence of dual role conflict variables and psychological well-being on the performance of female nurses in the S.K.Lerik Public Hospital Kupang City both partially and simultaneously. Limitations: This study only discusses the influence of multiple role conflict variables and psychological well-being on the performance of female nurses at the S.K.Lerik Regional Hospital in Kupang. Contribution: This research can be used as scientific information in the field of human resource management.
\end{abstract}

Keywords: Double Role Conflict, Psychological Well-Being, Performance.

Naskah diterima : 28-07-2020, Naskah dipublikasikan : 30-09-2020 


\section{PENDAHULUAN}

Negara Indonesia menjadi salah satu negara yang memberikan kesempatan bagi wanita untuk berkarir secara leluasa dan membuat angkatan kerja wanita Indonesia meningkat dari tahun ke tahun. Hal tersebut dikarenakan kemajuan pendidikan dan komitmen untuk mewujudkan emansipasi dalam berbagai dimensi kehidupan. Selain itu, pertumbuhan ekonomi yang sangat cepat juga mendorong partisipasi wanita dalam duani kerja, bukan sekedar pelengkap dan respon terhadap tuntutan persamaan hak dengan laki-laki, tetapi juga merupakan bentuk aktualisasi dirinya seorang wanita sebagai manusia yang bermanfaat bagi bangsa.

Saat ini sudah banyak wanita yang berkarya pada sektor publik sekaligus sebagai ibu rumah tangga. Wanita yang memiliki peran di ranah publik berdampak pada kurangnya waktu dan kualitas wanita dalam perannya sebagai istri, ibu dan pengelola rumah tangga. Bagi wanita yang telah berkeluarga dan memliki peran di ranah publik dalam hal ini wanita karir maka otomatis akan menimbulkan konflik peran ganda (Rissdy dalam Lovihan, \& Kaunang, 2010). Konflik peran ganda merupakan dua peran yang sekaligus melekat dalam diri seorang perempuan sebagai tenaga kerja dan juga sebagai ibu rumah tangga. Peran ganda terjadi karna perempuan yang bekerja mempunyai dua tujuan yang sama nilainya untuk mencapai keberhasilan dalam memelihara keluarga dan profesionalitas dalam bekerja. Peran ganda timbul akibat tekanan-tekanan yang berasal dari pekerjaan dan keluarga (Jamdin, 2015).

Dalam konteks ini, Appolo \& Cahyadi (2012) menegaskan bahwa konflik peran ganda yang terjadi pada saat seorang wanita berusaha memenuhi tuntutan peran dalam bekerja dan mampu memenuhi tuntutan peran di dalam keluarga, untuk menghindari peran ganda yang kepanjangan dalam menjalankan peran ini wanita juga harus menjaga kesejahteraan psikologi dirinya. Kesejahteraan psikologi merupakan kondisi seseorang yang menggambarkan hubungan seseorang pada objek ataupun orang lain dimana didalamnya terdapat keterikatan aktif, memahami arti dan tujuan hidup (Lopez S, \& Synder, 2007). Maka dapat dikatakan bahwa wanita yang memiliki kesejahteraan psikologi yang baik mampu mengatur dirinya sendiri dan mampu mengatasi berbagai macam masalah terkait dengan dirinya. Terabaikannya kesejahteraan psikis apabila tidak segera diatasi akan berdampak pada timbulnya stres kerja (Tarwaka, 2008 dalam Fitri, 2012).

Benturan peran ganda sangat dirasakan oleh tenaga medis wanita yang berprofesi sebagai perawat. Wagner et al (2010) menyatakan bahwa petugas layanan kesehatan, termasuk tenaga perawat, lebih cenderung mengalami stres atau tekanan pekerjaan daripada pekerja di sektor lain. Tenaga perawat merupakan sumber daya manusia yang jumlahnya paling dominan di rumah sakit, tenaga profesional yang perannya tidak dapat dikesampingkan dari semua bentuk pelayanan rumah sakit, peran ini disebabkan karena tugas perawat mengharuskan kontak paling lama dengan pasien. Berdasarkan uraian tésebut dapat dikatakan bahwa para perawat yang didominasi oleh wanita selalu berhadapan dengan konflik peran ganda sebagai tenaga medis professional dan sebagai ibu rumah tangga. Bukan tidak mungkin setiap perawat tersebut berusaha keras untuk dapat mengelola kesejahteraan psikisnya agar peran gandanya tidak member pengaruh buruk pada kinerjanya baik sebagai tenaga professional maupun sebagai wanita dalam keluarga.

Berdasarkan uraian di atas peneliti terdorong untuk melaukan penelitian tentang pengaruh peran ganda dan psychological well-being terhadap kinerja. Penelitian dilakukan pada para perawat RSUD S.K. Lerik Kota Kupang, Nusa Tenggara Timur dengan tujuan 1) Untuk menganalisis konflik peran ganda secara signifikan terhadap kinerja perawat wanita pada RSUD.S.K. Lerik Kota Kupang. 2) Untuk menganalisis pengaruh psychological well-being secara signifikan terhadap kinerja perawat wanita pada RSUD.S.K. Lerik Kota Kupang. 3) 
Untuk menganalisis pengaruh konflik peran ganda dan psychological well-being terhadap kinerja perawat wanita pada RSUD.S.K. Lerik Kota Kupang secara simultan.

\section{KAJIAN LITERATUR}

\section{Kinerja}

Menurut Mangkuprawira dan Hubeis (2007:157), Kinerja adalah hasil dari proses pekerjaan tertentu secara terencana pada waktu dan tempat dari karyawan serta organisasi bersangkutan. Kinerja merupakan output atau hasil kerja yang dihasilkan baik dari segi kualitas maupun kuantitas pekerjaanya dan dapat bertanggung jawabkan sesuai dengan perannya didalam organisasi dengan kemampuan, kecakapan dan keterampilan dalam menyelesaikan pekerjaan.

Menurut Prawirosentono (1999), kinerja adalah hasil kerja yang dapat dicapai oleh seseorang atau sekelompok orang dalam suatu organisasi sesuai dengan wewenang dan tanggung jawab masing-masing dalam rangkah upaya mencapai tujuan organisasi yang bersangkutan secara legal, tidak melanggar hukum dan sesuai dengan moral dan etika.Teori kinerja dalam hal ini adalah teori psikologis tentang proses tingkah laku kerja seseorangyang kemudian menghasilkan sesuatu yang menjadi tujuan dari pekerjaannya, perbedaan karakteristik individu yang satu dengan yang lain dapat menyebabkan berbedanya performa kerja atau dalam hal ini kinerjanya jika dihadapi dalam situasi yang berbeda.

Berdasarkan beberapa definisi tentang kinerja, maka kinerja adalah hasil kerja secara kualitas dan kuantitas seseorang yang dapat dilihat secara nyata dengan standar kerja dari sisi jumlah dan mutu sesuai dengan standart yang telah ditetapkan oleh organisasi atau perusahaan dalam mencapai tugas dan tanggung jawabnya yang diberikan kepadanya.

\section{Konflik Peran Ganda}

Manusia merupakan makhluk yang banyak memiliki kepentingan dalam hidupnya, apabila kepentingan-kepentingan itu datang secara bersama maka menciptakan konflik. Konfliks merupakan ketidak sesuaian antara dua atau lebih anggota-angota yang timbul karena adanya kenyataan bahwa mereka harus membagi sumber daya yang terbatas atau kegiatankegiatan kerja dan kenyataan bahwa mereka mempunyai perbedaan status, tujuan nilai atau persepei (Handoko 2000:346). Peran merupakan sekumpulan perilaku yang diharapkan oleh seseorang dari jabatan sebuah posisi, peran digunakan dalam lingkungan pekerjaana diharapkan dapat menjalankan perannya sesuai dengan apa yang diharapkan oleh pekerja tersebut (Kreitner dan Kinichi 2005). Peran yang dijalankan dalam hal ini peran wanita karir yang bekerja di luar rumah dalam mempertahankan suatu posisi dan cenderung menomor duakan keluarga.

Menurut Greenhaus \& Beutell (1985:77) konflik peran ganda merupakan bentuk konflik antara peran (interrole conflict) yang mana peran pekerjaan dan keluarga membutuhkan perhatian yang sama. Seseorang dikatakan mengalami konflik peran ganda apabila merasakan suatu ketagangan dalam peran pekerjaan dan keluarga, konflik peran ganda yang terjadi secara umum, diantaranya yaitu konflik disebabkan waktu, konflik disebabkan ketegangan dan konflik disebabkan perilaku. Konflik peran ganda biasa terjadi akibat lamanya waktu bekerja sehingga waktu dalam keluarga menjadi berkurang, individu yang menjalankan dua peran sekaligus dalam pekerjaan dan dalam keluarga akan menimbulkan tekanan dalam diri.

Berdasarkan beberapa definisi tentang konflik peran ganda, maka konflik peran ganda merupakan konflik yang terjadi pada seseorang perawat wanita yang menjalankan kedua peran secara bersamaan yaitu peran dalam keluarga dan peran dalam bekerja sehingga dapat terpengaruhinya salah satu peran akibat pemenuhan peranyang lainnya. 


\section{Psychological Well-Being}

Ryff \& Keyes (1995) Psychological well being merupakan kemampuan individu dalam menerima keadaan dirinya, membentuk hubungan yang hangat dengan orang lain, mampu mengendalikan dirinya dan mandiri terhadap tekanan sosial, serta mampu untuk merealisasikan potensi yang dimilikinya sehingga memiliki arti dalam hidupnya. Psychological well being tingkat kemampuan individu dalam menerima dirinya apa adanya, membentuk hubungan yang hangat dengan orang lain. Mandiri terhadap tekanan sosial, mengontrol lingkungan eksternal, memiliki arti dalam hidup, serta merealisasikan potensi dirinya secara kontinya, individu dikatakan memiliki kesejahteraan psikologis apabila secara otonomi menguasai lingkungannya, memiliki tujuan dan makna hidup, serta mengalami perkembangan kepribadian.

Menurut Synder dan Lopes (dalam Tenggara, dkk, 2008), Psychlogical well-being (kesejahteraan psikologis) bukan hanya merupakan ketiadaan penderitaan, namun kesejahteraan psikologis meliputi keterikatan aktif dalam dunia, memahami arti dan tujuan hidup dan hubungan seseorang pada objek ataupun orang lain. Individu yang memiliki Psychlogical well-being yang positif yaitu individu yang memiliki respon positif terhadap dimensi-dimensi Psychlogical well-being yang berkesinambungan.

Ryff (1989) mendifinisikan Psychlogical well-being sebagai suatu kondisi dimana individu memiliki sikap yang positif terhadap dirinya sendiri dan orang lain, dapat membuat keputusan sendiri dan mengatur tingkah lakunya sendiri, dapat menciptakan dan mengatur lingkungan yang kompatibel dengan kebutuhannya, memiliki tujuan hidup dan membuat hidup mereka lebih bermakna serta berusaha mengeksporasi dan mengembangkan diri.

Berdasarkan beberapa definisi tentang Psychlogical well-being, maka Psychlogical well-being merupakan kondisi diaman individu mampu menjalankan hal-hal positif dalam hidupnya, seperti membangun hubungan yang positif dengan orang lain dan bagaimana individu dapat berfungsi secara efektif dalam menjalankan kehidupan.

\section{Hubungan antara konflik peran ganda dan Psychologian wellbeing dengan kinerja.}

Konflik peran ganda mempengaruhi kinerja perawat dalam Rumah Sakit. Menurut Irwan ddk (1991) konflik dapat terjadi pada saat muncul dua kebutuhan atau lebih secara secara bersamaan. Menurut Robbins (1996) konflik adalah suatu proses diamna terjadi pertentangan dari suatau pemikiran yang dirasa akan membawa suatu pengaruh yang negatif.

Sedangkan Psychological well-being mempengaruhi kinerja perawat. Kimberly dan Utoyo (2013) kesejahteraan psikologi memiliki hubungan dimana peningkatan kondisi kesejahtraan psikologi akan mempengaruhi peninkatan dalam kinerja. Aiello dan Tesi (2017) mengemukakan bahwa, peningkatan kesejahteraan psikologi dapat dilihat dengan individu dalam mengembangkan potensi diri, dapat memotivasi diri sendiri jika hal ini timbul dalam diri seorang maka tingkat kesejahteraan psikologi berpengaruh baik terhadap kinerja.

Sianturi \& Zulkarnain (2013) perempuan yang mengalami peran ganda kemungkinan kurang mampu dalam menjalankan hal-hal positif dalam hidupnya karena kurang mampu menjalankan hal-hal positif tersebut sehingga dapat membuat 
pengaruh psychological wellbeing dirasakan rendah dan dapat membuat ibu yang bekerja lebih muda mengalami konfli peran ganda. Tinggi rendahnya konflik peran ganda wanita diduga dapat dipengaruhi oleh berbagai faktor salah satu faktor yang mempengaruhi adalah psychologian well-being semakin tinggi tingkat Work family conflict seseorang maka semakin rendah tingkat kesejahteraan psikologis.

Menurut Richdus (2011) konflik peran ganda sangatlah memengaruhi terhadap kinerja karyawan karena semakin tinggi konflik yang dihasilkan oleh individu seseorang maka seseorang dituntut mampu membagi tanggung jawabnya, individu di tuntut bertanggung jawab terhadap pekerjaannya dan mereka juga harus bertanggung jawab ke peran yang lain, perempuan yang memiliki peran ganda akan cenderung menurunkan kinerjanya.

\section{METODE PENELITIAN}

\section{Pendekatan Penelitian}

Pendekatan penelitian yang digunakan dalam penelitian ini adalah pendekatan kuantitatif, Metode penelitian kuantitatif menurut Sugiyono (2015:14) yaitu Metode yang berlandasan pada filsafat positivisme, digunakana untuk meneliti populasi penelitian, teknik pengambilan sampel umumnya dilakukan dengan cara memanfaatkan instrumen penelitian yang dipakai, analisis data digunakan bersifat kuantitatif atau biasa diukur dengan tujuan untuk menguji hipotesis yang ditetapkan sebelumnya.

\section{Populasi dan Sampel}

Populasi dalam penelitian ini adalah perawat wanita yang telah menikah pada RSUD S.K. Lerik Kota Kupang yang berjumlah 38 orang. Sampel adalah bagian dari populasi (sebagian atau wakil populasi yang diteliti) sampel penelitian ini adalah Sampling jenuh yaitu teknik penentuan sampel bila anggota populasi digunakan sebagai sampel. Hal ini dilakukan bila jumlah populasi relative kecil (Sugiyono 2016). Dengan demikian sampel dalam penelitian ini adalah sebanyak 38 orang dengan karakteristik khusus perawat wanita yang telah menikah.

\section{Teknik Analisis Data}

Analisis regresi linear berganda digunakan untuk mengetahuin seberapa besar pengaruh lebih dari satu variabel independen terhadap variabel dependen (Ghozali,2001). Persamaan regresi liner berganda dalam penelitian ini dapat di jelaskan sebagai berikut :

\begin{tabular}{cl} 
& \multicolumn{1}{c|}{$\mathbf{Y = a + \boldsymbol { \beta } \mathbf { X } 1 + \boldsymbol { \beta 2 X 2 } + \mathbf { e }}$} \\
$\mathrm{Y}:$ & Keterrangan : \\
$\mathrm{e}:$ & Standarja Error \\
$a:$ & Konstanta \\
$\beta 1 \beta 2:$ & Koefosien Regresi dari masing-masing variabel independen \\
$\mathrm{X} 1:$ & Konflik Peran Ganda \\
$\mathrm{X} 2:$ & Psychologial well-being
\end{tabular}




\section{HASIL DAN PEMBAHASAN}

Karakteristik responden berdasarkn jenis umur yang diperoleh dalam penelitian sebagai berikut:

Tabel Karakteristik Responden Berdasarkan Umur

\begin{tabular}{|c|c|c|}
\hline Usia Responden & Jumlah & Presentase \\
\hline 20-30 Tahun & 17 & 44,7 \\
\hline $31-40$ Tahun & 19 & 50,0 \\
\hline$\geq \square 41$ Tahun & 2 & 5,3 \\
\hline Jumlah & 38 & 100 \\
\hline
\end{tabular}

Sumber : Data primer diolah

Karakteristik responden berdasarkan umur perawat wanita dapat diketahui sebanyak 44,7 $\%$ berusia antara 20-30 tahun, 50,0 \% berusia antara 31-40 tahun, dan sisanya berada 5,3\% berada pada rentang usia $\geq 41$ tahun keatas. Menurut Soepriahanto (2009) perawat yang berusia lebih tua cenderung memiliki keterampilan dan kemampuan serta memiliki prestasi kerja yang lebih baik dibandingkan usia dibawahnya. Hal ini sejalan dengan penelitian yang dilakukan oleh Probowo et al.(2014) yang menyatakan bahwa usia mempengaruhi perilaku atau tindakan perawat khusunya dalam tindakan mengambil keputusan.

\section{Pengujian Asumsi Klasik}

Penggunaan untuk keyakinan bahwa persamaan garis regresi yang diperoleh adalah linier dan dapat dipergunakan (valid) untuk mencari peramalan, maka akan dilakukan pengujian asumsi multikoliniaritas, heteroskedasitas, dan normalitas.

\section{Uji Multikolinearitas}

Uji Multikolinearitas bertujuan untuk menguji apakah suatu model regersi terhadapat korelasi antara dua variabel bebas (idependen). Model regresi yang baik seharusnya tidak terjadi korelasi antara variabel independen. Pengujian multikolinearitas dilihat dari besaran VIF (Variance Infalation Factor) dan tolerens. Tolerens mengukur variabel idependen yang terpilih yang tidak dijelaskan oleh variabel idependen lainya. Jadi nilai tolerance yang rendah sama dengan nilai VIF tinggi (karena VIF $=1 /$ tolerance). Nilai cutoff yang umum dipakai untuk menunjukan adanya multikolinearitas adalah nilai tolerance $\geq 0,01$ atau sama dengan nilaiVIF $\leq 10$. (Ghozali. 2012.105).

\section{Uji Heteroskedastisitas}

Uji heteroskedastisitas bertujuan untuk menguji apakah dalam model regresi terjadi ketidaksamaan varian dari residual satu pengamatan ke pengamatan lain. Jika varian dari residual satu pengamatan ke pengamatan lain tetap, maka disebut homoskedastisitas dan jika berbeda disebut heteroskedasitas. (Ghozali, 2012:139).

\section{Uji Normalitas}

Uji normalitas bertujuan untuk mengetahui apakah dalam model regresi variabel dependen dan variabel idependen mempunyai kontribusi atau tidak. Model regresi yang baik adalah distribusi normal atau mendekati normal. (Ghozali,2012:160). 


\section{Analisis Regresi Linear Berganda}

Analisis regresi linear berganda digunakan dalam penelitian ini dengan tujuan untuk membuktikan hipotesis mengenai pengaruh variabel konflik peran ganda dan psychological well-being terhadap kinerja perawat. Perhitungan statistik dalam analisis regresi linear berganda yang digunakan dalam penelitian ini adalah dengan menggunakan bantuan SPSS. Hasil pengelohan data dengan menggunakan program SPSS selengkapnya ada pada lampiran tabel berikut in

Tabel Hasil Uji Regresi Linear Berganda

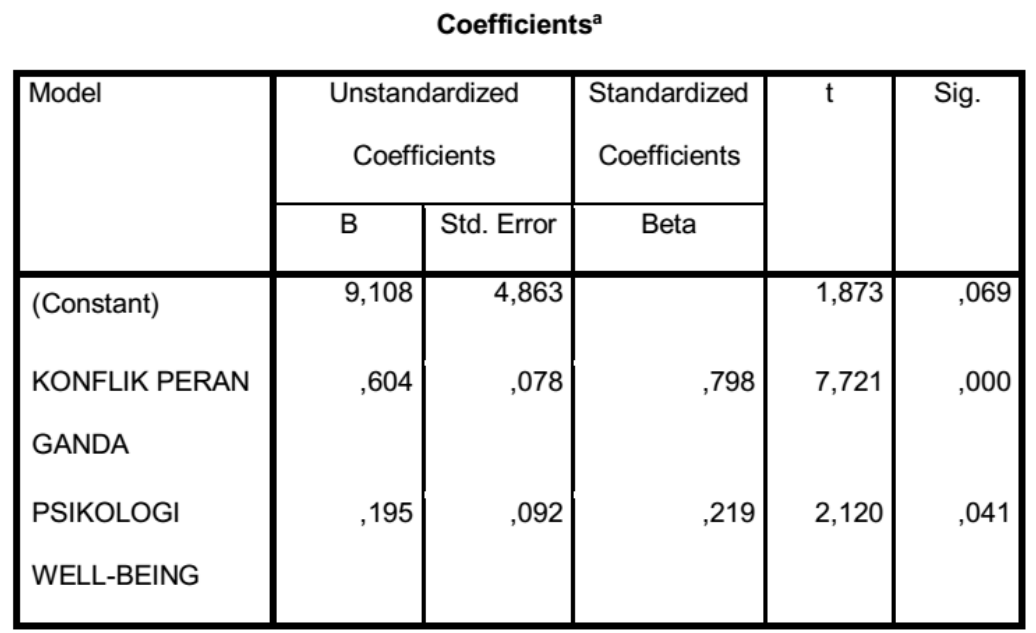

Sumber: Output Spss dari Data Primer (2019)

Dari tabel diatas dapat dibuat persamaan regresi berganda sebagai berikut:

$$
\mathrm{Y}=9,108+0,604 \mathrm{X} 1+0,195 \mathrm{X} 2
$$

Dari persamaan regresi diatas dapat diartikan sebagai berikut:

a. Berdasarkan hasi uji regresi yang diperoleh maka nilai kostanta adalah 9,108 artinya jika nilai dari konflik peran ganda dan psychological well-being sama dengan 0 maka nilai kinerja sebesar 9,108.

b. Koefisen regresi variabel konflik peran ganda sebesar 0,604 artinya jika nilai konflik peran ganda mengalami kenaikan sebesar 1 dan dapat dikendalikan oleh perawat maka kinerja perawat wanita akan mengalami kenaikan sebesar 0,604 satuan, dengan asumsi variabel pschological wellbeing (X2) tetap.

c. Koefisen regresi variabel pschological well-being sebesar 0,195 artinya jika nilai pschological well-being mengalami kenaikan sebesar 1 satuan maka kinerja perawat wanita akan mengalami kenaikan sebesar 0,195 satuan, dengan asumsi konflik peran ganda (X1) tetap.

\section{Uji Parsial (Uji t)}

Pada dasarnya uji statistik digunakan untuk melihat seberapa besar jauh pengaruh suatu variabel independen secara individu menerangkan variasi dari variabel dependen. Dengan syarat apabila nilai thitung lebih besar ttabel dan nilai signifikan lebih kecil 0,05 maka dapat disimpulkanbahwa variabel bebas secara parsial bepengaruh secara signifikan terhadap variabel terikat. Ada hasil uji t dapat dilihat pada tabel coefisien. 


\section{Pengaruh konflik peran ganda terhadap kinerja (H1)}

Dari tabel hasil uji parsial (t) diperoleh output thitung sebesar 7,721. Mencari thitung dengan derajat kebebasan $\mathrm{df}=\mathrm{n}-\mathrm{k}-1=38-2-1=35,(\mathrm{n}=$ jumlah responden, $\mathrm{k}=$ jumlah variabel independen). $\mathrm{a}=5 \%=0,05$, pengujian 2 sisi, signifikan $=0,05 / 2=0,025$ maka diperolah ttabel $=$ 2,024 (lihat tabel pada lampiran). Jika ttitung $\geq \square \mathrm{t}$ tabel maka HO ditolak dan Ha diterima, Jika ttitung $\leq \mathrm{t}$ tabel maka HO diterima dan Ha ditolak, Artinya konflik peran ganda berpengaruh secara parsial terhadap kinerja perawat wanita.

\section{Pengaruh psychologi well-being terhdap kinerja (H2)}

Dari tabel uji parsial $(\mathrm{t})$ diperoleh output thitung sebesar 2,120. Mencati tabel dengan derajat kebebasan $\mathrm{df}=\mathrm{n}-\mathrm{k}-1=38-2-1=35,(\mathrm{n}=$ jumlah responden, $\mathrm{k}=$ jumlah viriabel independen ) $\mathrm{a}=5 \%=0,05$, pengujian 2 sisi, signifikan $=0,05 / 2=0,025$, maka diperolah ttabel $=2,024$ ( lihat tabel $\mathrm{t}$ pada lampiran ). Jika ttitung $\geq \square \mathrm{t}$ tabel maka HO ditolak dan Ha diterima, Jika ttitung $\leq \mathrm{t}$ tabel maka HO diterima dan Ha ditolak. Artinya terbukti variabel psychologi well-being secara parsial berpengatuh terhadap kinerja perawat wanita.

\section{Uji Simultan Uji F (H3)}

Uji F dilakukan untuk melihat pengaruh variabel independen secara simultan terhadap variabel dependen. Pengujian ini dilakukan dengan cara menbandingkan nilai Fhitung dengan Ftabel. Apabila Fhitung > Ftabel dengan signifikan dibawah 0,05 (5\%) maka secara simultan variabel dependen berpengaruh signifikan terhadap variabel dependen, begitu pula sebaliknya. Pengujian hipotesis adalah sebagai berikut.

\section{Tabel Hasil Uji Simultan (F)}

ANOVA $^{\text {a }}$

\begin{tabular}{|l|r|r|r|r|r|}
\hline Model & \multicolumn{1}{c|}{$\begin{array}{c}\text { Sum of } \\
\text { Squares }\end{array}$} & \multicolumn{1}{c|}{$\begin{array}{c}\text { Mean } \\
\text { Square }\end{array}$} & F & Sig. \\
\hline Regression & 248,974 & 2 & 124,487 & 30,302 &, 000 \\
Residual & 143,789 & 35 & 4,108 & & \\
Total & 392,763 & 37 & & & \\
\hline
\end{tabular}

Dari tabel hasil uji simultan (F) diatas diperoleh otput Fhitung sebesar 30,302. Mencari Fhitung dengan derajat kebebasan df1 = jumlah seluruh variabel 3-1=2 df $2=\mathrm{n}-\mathrm{k}-1=38-2$ $1=35$, (n-jumlah responden, $\mathrm{k}$ - jumlah variabel independen). $\mathrm{a}=5 \%=0,05$, maka diperoleh Fhitung sebesar $=0,324$ ( lihat tabel F pada Lampiran ). Jika Fhitung $>$ Ftabel maka HO ditolak, Ha diterima, Jika Fhitung < Ftabel maka HO diterima, Ha ditolak. Fhitung $(30,302)>(0,324)$ maka Ho ditolak dan Ha diterima. Karena nilai Fhitung ( 30,302) > Ftabel $(0,324)$ maka Ho ditolak dan Ha diterima , artinya konflik peran ganda dan psychological well-being berpengaruh secara simultan terhadap variabel kinerja perawat. 


\section{Pengaruh Konflik Peran Ganda Terhadap Kinerja Perawat}

Dari hasil penelitian menunjukan bahwa konflik peran ganda mempengaruhi kinerja perawat wanita pada RSUD. S.K.Lerik Kota Kupang, konflik peran ganda menjadi salah satu faktor yang mempengaruhi kinerja perawat hal ini dikarenaka hampir dari perawat yang bekerja berstatus menikah yang dimana sering mengalami konflik antara pekerjaan dan keluarga, Perawat yang mengalami konflik peran ganda cenderung akan menurunkan kinerja. Anoraga(1992) menyebutkan bahwa konflik peran ganda merupakan suatu konflik atau pertentangan antara kepentingan pekerjaan dan kepentingan keluarga, dimana seringkali individu akan mengalami tekanan berkaitan dengan kedua kepentingan tersebut. Berdasarkan pengertian tersebut, dari hasil penelitian perawat wanita yang menjalankan dua peran sekaligus seringkali mengalami pertentangan dalam menjalankan aktifitas sehari-hari, baik itu pertentangan langsung dalam pekerjaan atau dalam keluaraga. Dengan demikian hasil penelitian ini di dukuang penelitian dari Sari (2016) dengan judul penelitian pengaruh psychological wellbeing dengan konflik peran ganda pada karyawati yang bekerja di Bank kaltim kota semarang. Dari hasil penelitian maka diketahui konflik peran ganda berpengaruh terhadap kinerja perawat wanita yang dimana jika konflik peran ganda dapat di kendalikan oleh perawat maka dapat memberikan pengaruh positif pada kinerja dari seorang perawat.

\section{Pengaruh Psychological Well-Being Terhadap Kinerja Perawat}

Dari hasil penelitian menunjukan bahwa psychological well-being mempengaruhi kinerja perawat wanita pada RSUD S.K.Lerik Kota Kupang. Rendahnya tingkat Pscyhological wellbeing yang timbul dalam kepribadian seorang perawat yang telah menikah seperti tekanan dalam bekerja maupun tekana dalam keluarga yang dimana Perawat yang rendahnya tingkat pschological well-being cenderung akan menurunkan kinerja. Ryff (1989) menyebutkan bahwa keadaan dimana individu mampu menerima dirinya apa adanya , mampu membentuk hubungan yang hangat dengan orang lain, memiliki kemandirian terhadap tekanan sosial, mampu mengontrol lingkungan ekternal, memiliki arti hidup, serta mampu merealisasikan potensi dirinya secara kontinyu. Berdasarkan pengertian tersebut seseorang yang memiliki tingkat psychological well- being yang rendah kondisi dimana seseorang bisa saja mengalami gangguan mental yang terjadi pada dirinya, tidak mampu mengontrol lingkungan eksternal dan sering mengalami tekanan sosial baik dalam pekerjaan maupun keluarga. Dengan demikian hasil penelitian ini mendukung hasil penelitian dari Perrewe et.al (1993). Dari hasil penelitian diketahui perawat wanita yang memiliki konflik perang ganda dalam keluarga cenderung memiliki tingkat psychological well-being yang rendah karna situasi dimana seorang perawat harus memposisikan diri antara dua situasi dimana kedua peran tersebut dijalankan dalam waktu yang bersamaan.

\section{Pengaruh Konflik Peran Ganda Dan Psychological Well-Being Terhadap Kinerja Persawat Wanita}

Dari hasil penelitian menunjukan bahwa Perawat wanita yang telah menikah pada RSUD. S.K.Lerik Kota Kupang cenderung memiliki konflik peran ganda yang mana dapat mempengaruhi tingkat psychological well-being yang dirasaka menurun, tinggi rendahnya konflik peran ganda wanita dapat dipengaruhi oleh faktor psychologian well-being semakin tinggi tingkat work family conflict seseorang maka semakin rendah tingkat kesejahteraan psikologi yang dirasakan oleh individu tersebut yang dapat menurunkan kinerja dari individu. Poelmans (2001) menyebutkan bahwa konflik peran ganda menimbulkan dampak negatif, baik terhadap wanita bekerja itu sendiri, keluarganya, maupun bagi organisasi tempat dia bekerja. Beberapa dampak negatif diantaranya adalah menurunkan kinerja dalam kehidupan rumah tangga, rendahnya psychological well-being dalam diri seseorang yang berdampak pada tekanan yang dirasakan dalam bekerja maupun dalam keluarga yang cenderung akan menurunkan kinerja individu. Dengan demikian hasil penelitian ini didukung denga penelitian dari Sianturi 
dan Zulkarnain (2013). Dari hasil penelitian yang dilakukan diketahui ada pengaruh konflik peran ganda dan psychological well-being terhadap kinerja perawat wanita.

\section{PENUTUP}

\section{Simpulan}

Berdasarkan hasil penelitian kuantitatif dengan mengunakan metode survei, wawancara dan dokumentasi yang dilakukan terhadapa perawat wanita pada RSUD S.K.Lerik Kota Kupang mengenai Pengaruh konflik peran ganda dan psychological well- being dapat diambil kesimpulan sebagai berikut: Hasil dari penelitian ini menunjukan bahwa variabel konflik peran ganda berpengaruh signifikan terhadap kinerja perawat wanita pada RSUD S.K.Lerik Kota Kupang. Hasil dari penelitian ini menunjukan bahwa variabel psychological wellbeing berpengaruh signifikan terhadap kinerja perawat wanita pada RSUD S.K.Lerik Kota Kupang. Hasil dari penelitian ini menunjukan pengaruh dari variabel konflik peran ganda dan psychological well-being terhadap kinerja perawat pada RSUD S.K.Lerik Kota Kupang. Hasil dari penelitian ini menunjukan pengaruh paling dominan dari variabel konflik peran ganda dan psychological well-being dilihat dari uji regresi linear berganda menunjukan koefisien konflik peran ganda lebih besar di bandingak koefisien psychological well-being.

\section{Saran}

Dalam penelitian ini hanya membahas bagaimana peran ganda dan psychological wellbeing berpengaruh pada kinerja saja. Peneliti selanjutnya dapat menambahkan variabel lainnya yang kemungkinan berpengaruh pada kinerja. Selain itu hasil penelitian tidak berlaku secara umum pada seluruh wanita yang memiliki peran ganda. Hasil bisa berbeda tergantung pada kondisi yang ada.

\section{REFERENSI}

Anoraga, P. 1992. Psikologi kepemimpinan. PT Rineka Cipta

Fitri, Azizah Musliha. 2013. Analisis Faktor-Faktor Yang Berhubungan Dengan Kejadian Stres Kerja Pada Karyawan Bank (Studi pada Karyawan Bank BMT). Jurnal Kesehatan Masyarakat, Volume 2, Nomor 1, Tahun 2013

Ghozali, I.,2001. Aplikasi Analisis dengan program SPSS.Semarang: Badan Penerbit Universitas Diponegoro, 2001

Greenhaus, J. H., \& Beutell, N.J.(1985). Soutces of conflict between work and family roles, Academy of Managemen Review, 10, 76-88.

Handoko , T. Hani, 2000 “ Manajemen Sumber Daya Manusia “ Yogyakarta : BPFE

Keyes, C., \& Ryff, C. (1995). The Strructure of Psychological Well-Being Resivited. Journal of Personality and Social Psychology

Kimberly \& Utoyo, S.D.B. (2013). Hubungan Psychological Well Being dan Work Engagement Pada Karyawan yang Bekerja di Lokasi Tambang. Paper dipresentasikan di Fakultas Psikologi, Universitas Indonesia.

Kreitner, Robert and Angelo Kinicki, 2005 Perilaku Organisasi (Orgaizatioohan Behavior) Jakarta Selemba Empat. 
Lopez, S., \& Synder, C. (2007). Positive Psychology : The Scientific and Practical Explorations of Human Stregth.

Lovihan, M. A.K., Kaunang, R. O. W. (2010). Perbedaan perilaku arsetif pada wanita karier yang sudah menikah dengan yang belum menikah di minahasa. INOVASI, 7, (4), 240250 .

Mangkuprawira, TB.S dan A.V. Hubeis. 2007. Manajemen Mutu Sumber Daya Manusia. Ghalia Indonesia, Bogor.

Perrewe, Pamela L.; Fernandez, Denise Rotondo; Morton, Karen S. (Dec., 1993), An Experimental Examination of Implicit Stress Theory. Journal of Organizational Behavior. Vol. 14, No. 7 (Dec., 1993), pp. 677-686.

Poelmans, S. (2001). Cómo armonizar trabajo y familia en el nuevo siglo. In: Paradigmas del Liderazgo. McGraw-Hill Interamericana de España, Chapter 13, pp. 195-211.

Probowo, Anis Gambaran Tingkat Pengetahuan Mahasiswa Tingkat I Prodi D Iii Keperawatan Tentang Manajemen Stres Di Sekolah Tinggi Ilmu Kehatan (Stikes) PKU Muhammadiyah Surakarta

Ryff , C,D. (1989). Happiness is everything, or is it? Exploration on the meanin psychological well-being. Journal of Personality and Social Psychology, 57,1069-1081.

Ryff, C. D., \& Keyes, C.L ( 1995). The structure of psychologial well-being revisited. Journal of Personnel social Psychology, 69(4), 719-727.

Ryff , C.,\& Singer, B. (2008). Know thyself and become what you are: A eudaimonic approach to psychological well-being, Journal of Happiness Studies, 9, 13-39.

Sianturi, M. M., \& Zulkarnain. (2013). Analisis Work Family Conflict terhadap Kesejahteraan. Psikologis Pekerja. Jurnal Sains dan Praktik Psikologi, I, 205-217.

Singer, B., \& Ryff, C. (1996). Psychological Well-Being : Meaning, Measurement, and Implications for Psychoterapy Research. Psychotherapy Psychosomatics, 65, 14-23.

Sugiyono. (2009). Metode Penelitian Kuantitatif Kualitatif dan R\&D. Bandung: Alfabeta.

Tenggara, H., Zamralita, \& Suyasa, P.T.Y.S. (2008). Kepuasan Kerja dan Kesejahteraan Psikologis Karyawan. Phronesis Jurnal Ilmiah Psikologi Industri dan Organisasi, 10(1),96-115 .

Tesi, A., Aiello, A., \& Giannetti, E. (2018). The work-related well-being of social workers: Framing job demands, psychological well-being, and work engagement. Journal of Social Work, 1-21 